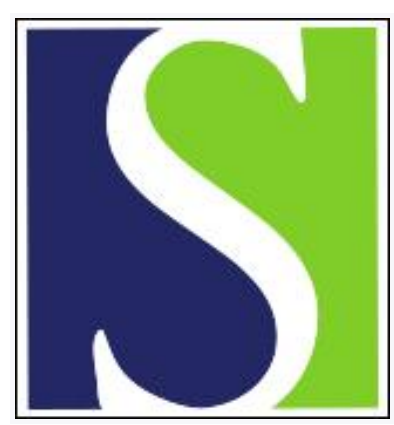

Scand J Work Environ Health 1990;16(4):252-257

https://doi.org/10.5271/sjweh.1787

Issue date: 01 Aug 1990

Cancer risk among health care personnel in Finland, 1971-1980.

by Sankila R, Karjalainen S, Laara E, Pukkala E, Teppo L

Affiliation: Finnish Cancer Registry, Helsinki.

This article in PubMed: www.ncbi.nlm.nih.gov/pubmed/2389132

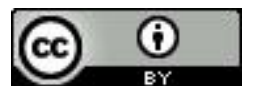




\title{
Cancer risk among health care personnel in Finland, 1971-1980
}

\author{
by Risto Sankila, MD, ${ }^{1}$ Sakari Karjalainen, MD, ${ }^{1}$ Esa Läärä, MSc, ${ }^{2}$ Eero Pukkala, MA, ${ }^{1}$ \\ Lyly Teppo, MD ${ }^{1}$
}

\begin{abstract}
SANKILA R, KARJALAINEN S, LÄÄRÄ E, PUKKALA E, TEPPO L. Cancer risk among health care personnel in Finland, 1971-1980. Scand J Work Environ Health 1990;16:252-7. Standardized incidence ratios were calculated for the assessment of cancer risk among Finnish health care personnel in 19711980. The overall relative cancer risk among the men was low when compared with that of all economically active men, mainly due to the low relative risk of lung cancer. The cancer risk of female health care personnel was increased when compared with that of all economically active women. The relative risk of breast cancer among registered nurses was high, being twice that of practical nurses, who had an average risk. In contrast, the risk of lymphomas, leukemia, and primary liver carcinoma was low among registered nurses and high among practical nurses. Although specific occupational exposures could not be assessed, the results did not imply any alarming major hazards related to health care work itself.
\end{abstract}

Key terms: neoplasms, nurses, occupational diseases, physicians.

Health care personnel face potential risks of cancer in their occupational environment, particularly from exposure to ionizing radiation (1-5) and cytostatic drugs (6). In patient care there is a risk of exposure to viruses associated with various cancers, such as the hepatitis-B virus (primary hepatoma) and the Epstein-Barr virus (nasopharyngeal carcinoma and Burkitt's lymphoma) (7). Hodgkin's disease may have a viral etiology $(8,9)$, and certain malignancies (eg, Kaposi's sarcoma and non-Hodgkin's lymphomas) are connected with infections caused by human immunodeficiency viruses $(10-12)$. Exposure to anesthetic gases has been suspected of increasing the risk of cancer among operating-room personnel (13-17). Ethylene oxide, a sterilizing agent, has been suspected of increasing the risk of leukemia (18-21).

With the exception of the documented increase in the incidence of cancer among radiologists and other radiation workers early in this century (1), there is no evidence of increased cancer risks caused by occupational exposures in health care. As long as radiation exposure has not exceeded current safety standards, it has not been possible to attribute cancer cases to radiation (1).

On the other hand, occupational safety standards are strict in this field, and the avoidance of occupational health hazards is emphasized in both basic and continued education. New, and even unlikely, risk factors are readily reported in the literature (22). Hence,

1 Finnish Cancer Registry, Helsinki, Finland.

2 Medical Research Council of Finland and Department of Applied Mathematics and Statistics, University of Oulu, Oulu, Finland.

Reprint requests to: Dr R Sankila, Finnish Cancer Registry, Liisankatu 21 B, SF-00170 Helsinki, Finland. the potential occupational risk factors may, indeed, be of minor importance in the cancer morbidity of health care personnel.

This descriptive study was carried out to estimate the relative cancer risks of different health care occupations.

\section{Subjects and methods}

In the 1970 population census of Finland, information on occupation was recorded for 4.6 million people ( $98 \%$ of the total population) living in the country on 31 December 1970. The information on occupation from the census was linked with the files of the Finnish Cancer Registry for patients aged 25 to 64 years with a diagnosis of cancer in 1971-1980. This linkage used the unique personal identification number given to everyone residing in Finland. The material consisted of 22046 cases of cancer among economically active men and 16806 cases of cancer among economically active women.

The population-based, nationwide Finnish Cancer Registry has been in operation since 1953. All physicians, hospitals, and pathological laboratories are obligated to report all new cancer cases that come to their attention. The Central Statistical Office of Finland informs the Registry of all death certificates on which cancer is mentioned. The Registry data have been shown to be reliable, and their coverage is virtually' complete (23).

In the census, occupations were coded according to a modification of the Nordic Classification of Occupations (24), which is equivalent to the International Standard Classification of Occupations (25). Health care personnel were divided into 10 entities: physicians (code 030), dentists (code 031), registered nurses (code 
032), dental nurses and receptionists (code 033), midwives (code 034), psychiatric nurses (code 035), practical nurses and orderlies (code 036), technical assistants (code 037), childrens' nurses (code 038), and a small group of miscellaneous hospital-related occupations, such as patient hostesses and hospital maintenance men (code 039). For the sake of brevity, dental nurses and receptionists have been referred to as dental nurses in this report. The group of practical nurses and orderlies is referred to as orderlies when the results for the men are being presented and as practical nurses when the women are being discussed. Pharmacists, physiotherapists, health officers, masseurs, and a few other very small groups of people in occupations related to health care were excluded from this analysis.

The standardized incidence ratios were calculated by dividing the observed numbers of cancers by the corresponding expected numbers. The expected numbers were obtained by multiplying the age-, sex-, and occupation-specific person-years for 1971-1975 and 1976-1980 (provided by the Central Statistical Office of Finland) by the age-, sex-, and period-specific incidence rates (number of cases per person-year) of the total economically active population.

The observed numbers of cases were assumed to follow a Poisson distribution. The $95 \%$ confidence intervals were calculated for the standardized incidence ratios from the tabulated confidence intervals of the Poisson mean (26). The $95 \%$ confidence intervals for the ratios between the standardized incidence ratios of the registered and practical nurses were calculated by the exact binomial method with the fractiles of the appropriate $\mathrm{F}$ distributions (27). A more-detailed comparison was made of the overall and age-specific incidences of breast cancer between the registered and practical nurses with the use of the Poisson log-linear model and maximum likelihood fitting in the statistical analysis (27).

\section{Results}

Among the male health care personnel (code 03) the cancer risk, based on 63 cases, was lower, with a standardized incidence ratio (SIR) of 64, than that of all economically active men (table 1). Physicians (code 030) produced $51 \%$ of the person-years at risk among the male health care personnel and constituted the only occupational group among the men with a significantly lower cancer risk (SIR 60) than that of all economically active men (28). In the other low-risk occupations (dentists and psychiatric nurses) the numbers of cases were small, and thus the confidence intervals were wide (table 1).

The relative risk of lung cancer was very low among the male health care personnel and in particular among male physicians (SIR 28 and 25, respectively) (table 1). There were no lung cancer cases among the male dentists (3.5 expected) (table 1). Zero to four cases were observed at other primary sites among the male health care personnel, and the estimated relative risks did not significantly differ from unity.

An elevated cancer risk (SIR 122), as compared with that of all economically active women, was noted for the female health care personnel on the basis of 1089 cases. The two largest health care occupations of registered nurses and practical nurses among the women differed in their cancer risk. Registered nurses had an increased relative risk of cancer (SIR 150), but practical nurses had an average incidence (SIR 104). Dental nurses, midwives, psychiatric nurses, technical assistants, and childrens' nurses also had an elevated risk of cancer (SIR 121-138) (table 2).

The risk of breast cancer was higher than average amon: the female health care personnel (SIR 137) (table 2). Physicians had an average incidence of breast cancer, but dentists had an elevated risk (SIR 153). These figures are, however, based on small numbers and have wide confidence intervals. The relative risk of breast cancer was high among the registered nurses

Table 1. Observed and expected numbers and the standardized incidence ratios with their $95 \%$ confidence intervals for al cancers and lung cancer among the male health care personnel, aged 25-64 years, by occupation in Finland in $1971-1980$. ( $\mathrm{SIR}=$ standardized incidence ratio, $95 \% \mathrm{Cl}=95 \%$ confidence interval)

\begin{tabular}{|c|c|c|c|c|c|c|c|c|}
\hline \multirow{2}{*}{$\begin{array}{l}\text { Occupational } \\
\text { group }\end{array}$} & \multicolumn{4}{|c|}{ All cancers } & \multicolumn{4}{|c|}{ Lung cancer } \\
\hline & Observed & Expected & SIR & $95 \% \mathrm{Cl}$ & Observed & Expected & SIR & $95 \% \mathrm{Cl}$ \\
\hline All economically active men & 22046 & . & 100 & . & 6910 & . & 100 & $\cdot$ \\
\hline Health care personnel (03) & 63 & $98.5^{b}$ & 64 & $49-82$ & 8 & $28.5^{b}$ & 28 & $12-55$ \\
\hline $\begin{array}{l}\text { Physicians }^{c}(030) \\
\text { Dentists }(031) \\
\text { Psychiatric nurses (035) } \\
\text { Orderlies (036) } \\
\text { Miscellaneous (039) }\end{array}$ & $\begin{array}{r}33 \\
6 \\
10 \\
2 \\
12\end{array}$ & $\begin{array}{r}55.0 \\
11.8 \\
14.5 \\
1.1 \\
14.5\end{array}$ & $\begin{array}{r}60 \\
51 \\
69 \\
181 \\
83\end{array}$ & $\begin{array}{l}41-84 \\
19-111 \\
33-127 \\
22-657 \\
43-145\end{array}$ & $\begin{array}{l}4 \\
-1 \\
1 \\
2\end{array}$ & $\begin{array}{r}16.2 \\
3.5 \\
3.7 \\
0.2 \\
4.5\end{array}$ & $\begin{array}{r}25 \\
0 \\
28 \\
476 \\
44\end{array}$ & $\begin{array}{r}7-63 \\
0-105 \\
1-151 \\
12-2652 \\
5-161\end{array}$ \\
\hline
\end{tabular}

a Codes of the Nordic Classification of Occupations (24) in parentheses.

b Includes occupations with no observed cases, such as male registered nurses.

c Incidence data originally published by Nurminen et al (28). 
Table 2. Observed and expected numbers and the standardized incidence ratios with their $95 \%$ confidence intervals for all cancers and breast cancer among the female health care personnel, aged 25-64 years, by occupation in Finland in 1971-1980. (SIR = standardized incidence ratio, $95 \% \mathrm{Cl}=95 \%$ confidence interval)

\begin{tabular}{|c|c|c|c|c|c|c|c|c|}
\hline \multirow{2}{*}{$\begin{array}{l}\text { Occupational } \\
\text { group }^{\mathrm{a}}\end{array}$} & \multicolumn{4}{|c|}{ All cancers } & \multicolumn{4}{|c|}{ Breast cancer } \\
\hline & Observed & Expected & SIR & $95 \% \mathrm{Cl}$ & Observed & Expected & SIR & $95 \% \mathrm{Cl}$ \\
\hline All economically active women & 16806 & · & 100 & . & 5200 & $\cdot$ & 100 & $\cdot$ \\
\hline Health care personnel $(03)$ & 1089 & 890.7 & 122 & $115-130$ & 394 & 287.2 & 137 & $124-151$ \\
\hline $\begin{array}{l}\text { Physicians }(030) \\
\text { Dentists }(031) \\
\text { Registered nurses (032) } \\
\text { Dental nurses (033) } \\
\text { Midwives (034) } \\
\text { Psychiatric nurses (035) } \\
\text { Practical nurses (036) } \\
\text { Technical assistants (037) } \\
\text { Childrens' nurses (038) } \\
\text { Miscellaneous (039) }\end{array}$ & $\begin{array}{r}19 \\
42 \\
392 \\
30 \\
46 \\
74 \\
399 \\
13 \\
71 \\
3\end{array}$ & $\begin{array}{r}21.6 \\
37.2 \\
261.2 \\
21.7 \\
38.0 \\
58.6 \\
383.9 \\
9.5 \\
55.1 \\
3.8\end{array}$ & $\begin{array}{r}88 \\
113 \\
150 \\
138 \\
121 \\
126 \\
104 \\
137 \\
129 \\
79\end{array}$ & $\begin{array}{r}53-137 \\
81-153 \\
136-166 \\
93-197 \\
89-161 \\
99-159 \\
94-115 \\
73-234 \\
101-163 \\
16-239\end{array}$ & $\begin{array}{r}7 \\
17 \\
163 \\
11 \\
18 \\
24 \\
116 \\
2 \\
33 \\
3\end{array}$ & $\begin{array}{r}6.8 \\
11.1 \\
83.0 \\
6.7 \\
12.8 \\
19.5 \\
124.7 \\
3.1 \\
18.3 \\
1.2\end{array}$ & $\begin{array}{r}102 \\
153 \\
196 \\
165 \\
141 \\
123 \\
93 \\
64 \\
180 \\
250\end{array}$ & $\begin{array}{r}41-211 \\
89-245 \\
167-228 \\
82-295 \\
83-222 \\
79-183 \\
77-112 \\
8-233 \\
124-253 \\
52-731\end{array}$ \\
\hline
\end{tabular}

a Codes of the Nordic Classification of Occupations (24) in parentheses.

Table 3. Observed and expected numbers and the standardized incidence ratios with their $95 \%$ confidence intervals for the most common cancers among the female health care personnel, aged 25-64 years, in Finland in 1971-1980. (SIR = standardized incidence ratio, $95 \% \mathrm{Cl}=95 \%$ confidence interval)

\begin{tabular}{lrrrr}
\hline Site & Observed & Expected & SIR & \multicolumn{1}{c}{$95 \% \mathrm{CI}$} \\
\hline Liver & 9 & 4.6 & 197 & $89-371$ \\
Rectum & 95 & 22.9 & 153 & $106-213$ \\
Leukemia & 28 & 19.3 & 145 & $96-210$ \\
Breast & 394 & 287.2 & 137 & $124-151$ \\
Melanoma of the skin & 46 & 34.4 & 134 & $98-178$ \\
Stomach & 59 & 45.3 & 130 & $99-168$ \\
Kidney & 23 & 18.5 & 124 & $79-187$ \\
Colon & 44 & 35.7 & 123 & $90-165$ \\
All sites & 1089 & 890.7 & 122 & $115-130$ \\
Nervous system & 58 & 48.5 & 120 & $91-155$ \\
Ovary & 85 & 72.2 & 118 & $94-146$ \\
Thyroid gland & 36 & 31.5 & 114 & $80-158$ \\
Lung & 31 & 27.7 & 112 & $76-159$ \\
Corpus uteri & 73 & 66.3 & 110 & $86-138$ \\
Cervix uteri & 33 & 47.1 & 70 & $48-98$ \\
\hline
\end{tabular}

(SIR 196), childrens' nurses (SIR 180), dental nurses (SIR 165), and midwives (SIR 141). Practical nurses, however, had an SIR of 93, which was slightly lower than the average (table 2), but significantly lower than the risk of breast cancer in the other health care occupations combined (SIR 171).

The risk of cancer was higher for most primary sites among the female health care personnel than among the economically active women as a whole (table 3). The relative risks were highest for cancer of the liver (SIR 197) and rectum (SIR 153), leukemia (SIR 145), and breast cancer (SIR 137). The risks of melanoma of the skin and cancers of the stomach, kidney, and colon were also elevated. Only the risk of cancer of the uterine cervix was low (SIR 70) (table 3).

Table 4. Observed numbers and the standardized incidence ratios for selected cancers among the female registered nurses and practical nurses, aged 25-64 years, in Finland in 1971-1980 with their $95 \%$ confidence intervals and the ratios between the SIR values of the registered and practical nurses with their $95 \%$ confidence intervals. (SIR = standard incidence ratio, $95 \% \mathrm{CI}=95 \%$ confidence interval, RSIR = SIR for registred nurses : SIR for practical nurses)

\begin{tabular}{|c|c|c|c|c|c|c|c|c|}
\hline \multirow{2}{*}{ Site } & \multicolumn{3}{|c|}{ Registered nurses } & \multicolumn{3}{|c|}{ Practical nurses } & \multirow{2}{*}{ RSIR } & \multirow{2}{*}{$95 \% \mathrm{Cl}$} \\
\hline & Observed & SIR & $95 \% \mathrm{Cl}$ & Observed & SIR & $95 \% \mathrm{Cl}$ & & \\
\hline Breast & 163 & 196 & $168-229$ & 116 & 93 & $77-111$ & 2.11 & $1.65-2.70$ \\
\hline Corpus uteri & 32 & 176 & $120-270$ & 28 & 96 & $64-138$ & 1.83 & $1.07-3.16$ \\
\hline Colon & 15 & 145 & $81-238$ & 15 & 97 & $55-161$ & 1.49 & $0.68-3.28$ \\
\hline Rectum & 12 & 186 & $97-327$ & 13 & 129 & $69-222$ & 1.44 & $0.60-3.43$ \\
\hline All sites & 392 & 150 & $136-166$ & 399 & 104 & $94-115$ & 1.44 & $1.25-1.66$ \\
\hline Nervous system & 24 & 156 & $100-232$ & 23 & 114 & $72-170$ & 1.37 & $0.74-2.54$ \\
\hline Kidney & 7 & 132 & $53-246$ & 8 & 100 & $43-197$ & 1.32 & $0.41-4.17$ \\
\hline Stomach & 20 & 153 & $93-236$ & 23 & 117 & $74-176$ & 1.31 & $0.68-2.49$ \\
\hline Lung & 9 & 114 & $52-216$ & 11 & 91 & $45-163$ & 1.25 & $0.46-3.33$ \\
\hline Melanoma (skin) & 16 & 146 & $82-236$ & 18 & 126 & $75-199$ & 1.16 & $0.55-2.41$ \\
\hline Thyroid gland & 13 & 128 & $68-218$ & 16 & 123 & $70-200$ & 1.04 & $0.46-2.31$ \\
\hline Ovary & 23 & 108 & $68-162$ & 34 & 109 & $75-152$ & 0.99 & $0.56-1.73$ \\
\hline Cervix uteri & 10 & 73 & $35-134$ & 18 & 89 & $53-140$ & 0.82 & $0.34-1.87$ \\
\hline Hodgkin's disease & 4 & 98 & $27-250$ & 7 & 151 & $61-314$ & 0.65 & $0.14-2.55$ \\
\hline Non-Hodgkin's lymphomas & 3 & 75 & $15-219$ & 9 & 159 & $72-300$ & 0.47 & $0.08-1.89$ \\
\hline Leukemia & 3 & 51 & $10-149$ & 14 & 172 & $93-271$ & 0.30 & $0.05-1.06$ \\
\hline Liver & 1 & 76 & $2-422$ & 5 & 253 & $82-589$ & 0.30 & $0.01-2.68$ \\
\hline
\end{tabular}




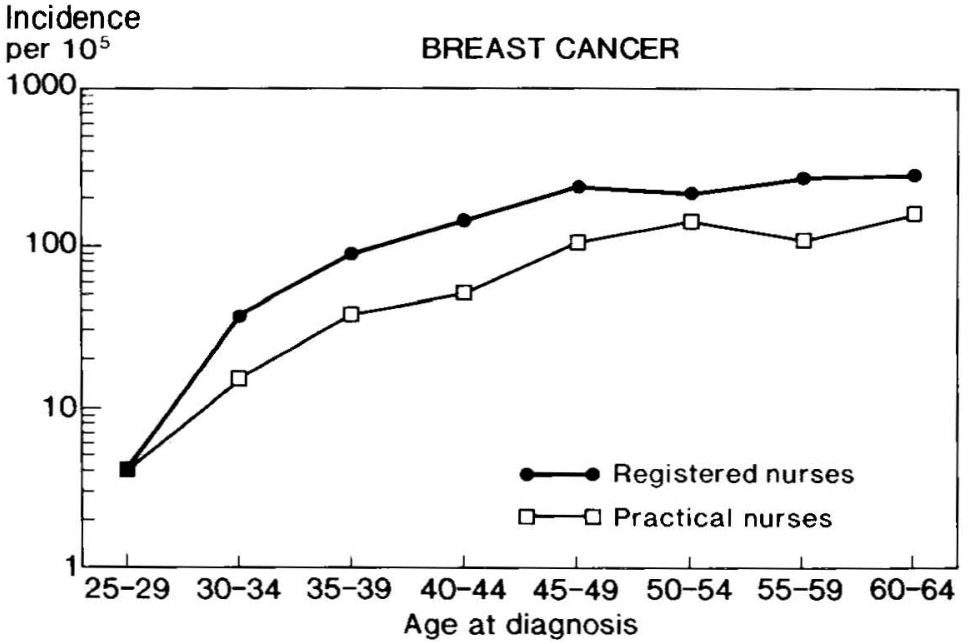

Figure 1. Age-specific incidence rates for breast cancer among registered nurses and practical nurses in Finland, 1971-1980. (Age at diagnosis in years)
Whereas registered nurses had a high relative risk for cancers of the breast (SIR 196), uterine corpus (SIR 176), and colon (145), practical nurses had incidences close to the average for these cancers (table 4). The situation was reversed for lymphomas, leukemia, and primary hepatoma. Registered nurses had an average or low relative risk and practical nurses a high relative risk (table 4). The lymphoma, leukemia, and liver carcinoma cases were, again, rather few.

The age-specific incidence rates for breast cancer were consistently higher for registered nurses than for practical nurses (figure 1). The ratio of the age-specific incidence rates of these two groups did not vary significantly with age. The age-adjusted estimate of the overall relative risk from the log-linear model was 2.14 (95\% CI 1.69-2.72), almost the same as the ratio between the standardized incidence ratios (ie, 2.11) (table 4).

\section{Discussion}

Both the incidence of and mortality from cancer have been low among Finnish physicians (28-30). Cancer mortality has been reported to be low among physicians in other countries, too $(31,32)$. Finnish physicians smoke less than the general population $(33,34)$, and their lung cancer risk is lower than that of other professions (35). The risk of cancer mortality related to smoking has been studied among British physicians (36), but otherwise there are few recent data on cancer incidence and mortality for the different medical professions $(37-42)$ other than for radiologists $(1-4)$ and anesthesiologists $(13,14,16,17)$.

In this study more than half of the deficit in the relative cancer morbidity for male health care personnel could be explained by low morbidity from lung cancer ( 8 observed versus 28.4 expected), which is the most common cancer among Finnish men (43). Lung cancer also explained more than half of the decrease in the overall relative cancer risk among male physicians. The low lung cancer risk is likely due to the low prevalence of smokers $(33,34)$.

The women in health care occupations had an elevated risk of cancer. Half of the excess risk could be explained by the excess of breast cancer. It seems unlikely that occupational factors would have had much effect on breast cancer morbidity, but the excess risk and the occupational group differences probably reflect the distribution of the general risk indicators for breast cancer, such as hormonal and lifestyle factors (44).

Practical nurses had a high relative risk of lymphomas, leukemia, and liver carcinoma, whereas registered nurses had an average or low relative incidence of these cancers. Radiation, ethylene oxide, and infections have been suspected of being etiologic factors for these tumors $(5,7,8,19)$. There are no relevant data about the prevalence of exposure to these agents among all nurses nationwide in Finland. In a case-referent study on spontaneous abortions and malformations in the offspring of nurses, Hemminki et al (45) assessed exposure prevalences among 638 pregnant nurses working in certain departments of general hospitals. In this selected group $30 \%$ of the pregnant nurses were exposed to anesthetic gases, $6 \%$ to ethylene oxide, $9 \%$ to cytostatic drugs, and $34 \%$ to $\mathrm{X}$-rays in undefined quantities. The authors suspected that nurses working in operating rooms had been exposed to negligible levels of ethylene oxide since only a few of them had been involved in actually sterilizing the instruments (45). In the Portland-Vancouver metropolitan area the risks of both lymphatic and nonlymphatic leukemia were significantly elevated among registered and practical nurses (42). On the basis of our study we cannot rule out the possibility that the excess risk is attributable to occupational risk factors.

The standardized incidence ratios of different occupational groups are not necessarily strictly comparable (27). The ratio between two standardized incidence 
ratios may give a biased estimate of the relative risk between two groups if the age distributions are different and if the relative risk varies greatly across the age categories. In our data, registered nurses had a somewhat different age distribution than practical nurses. For breast cancer the age-specific relative risks were fairly homogeneous, and the adjusted estimate of the overall risk ratio was not materially different from the ratio between the standardized incidence ratios (table 4 and figure 1). As the numbers of cases in individual age groups are generally very small for most cancers, any heterogeneity test (27) would be very insensitive. Nevertheless, the possible bias from this source is probably relatively small in comparison with the magnitude of random error in the relative risk estimates.

In this study, we did not assess specific exposures, and thus it was not possible to estimate the effects of specific occupational risk factors. Our results indicate that there is an increased risk of cancer among female health care personnel, although some of the significant standardized incidence ratios may have been due to the multiple comparisons made. The risk differences between the occupational groups call for further study.

We were only able to analyze the cancer risks of those individuals who were economically active in 1970 , as the former occupations of people retired before 1970 were unknown. Considering the long latency of solid tumors and the large proportion of old cancer patients, future studies should also include the retired people with the longest work exposures. With the case-referent approach, the specific exposures (radiation, cytostatics, etc) of health care personnel should be evaluated. Data should also be collected at the individual level on employment histories and personal risk factors such as smoking, hormonal and reproductive history, infectious diseases, and social status.

\section{Acknowledgments}

This study was supported by the Finnish Work Environment Fund.

\section{References}

1. Archer VE. Occupational exposure to radiation as a cancer hazard. Cancer 1977;39:1802-6.

2. Baker DG. Radiology, is there an occupational hazard? Am Ind Hyg Assoc J 1988;49:17-20.

3. Court Brown WM, Doll R. Expectation of life and mortality from cancer among British radiologists. $\mathrm{Br}$ Med J 1958;2:181-7.

4. Logue JN, Barrick MK, Jessup GL. Mortality of radiologists and pathologists in the radiation registry of physicians. J Occup Med 1986;28:91-9.

5. Rantanen J. Radiation carcinogenesis. J Toxicol Environ Health 1980;6:971-6.

6. Sorsa $\mathbf{M}$, Hemminki $\mathrm{K}$, Vainio $\mathrm{H}$. Occupational exposure to anticancer drugs potential and real hazards. Mutat Res 1985;154:135-49.

7. Evans AS. Viruses. In: Schottenfeld D, Fraumeni JF Jr, ed. Cancer epidemiology and prevention. Philadelphia,
PA: WB Saunders, 1982:370-81.

8. Grufferman S, Delzell E. Epidemiology of Hodgkin's disease. Epidemiol Rev 1984;6:76-106.

9. Vianna NJ, Polan AK, Keogh MD, Greenwald P. Hodgkin's disease mortality among physicians. Lancet 1974; 2:131-3.

10. Centers for Disease Control. Update: acquired immunodeficiency syndrome and human immunodeficiency virus infection among health-care workers. Morb Mortal Wkly Rep 1988;37:229-39.

11. Kaplan MH, Susin M, Pahwa SG, Fetten J, Allen SL, Lichtman S. Neoplastic complications of HTLV-III infection: lymphomas and solid tumours. Am J Med 1987; 82:389-96.

12. Levine AM. Non-Hodgkin's lymphomas and other malignancies in the acquired immune deficiency syndrome. Semin Oncol 1987;14(suppl 3):34-9.

13. Ad hoc Committee on the Effect of Trace Anesthetics on the Health of Operating Room Personnel, American Society of Anesthesiologists. Occupational diseases among operating room personnel: a national study. Anesthesiology 1974;41:321-40.

14. Buring JE, Hennekens $\mathrm{CH}$, Mayrent SL, Rosner B, Greenberg ER, Colton T. Health experiences of operating room personnel. Anesthesiology 1985;62:325-30.

15. Corbett TH, Cornell RG, Lieding K, Endres JL. Incidence of cancer among Michigan nurse-anesthetists. Anesthesiology 1973;35:260-3.

16. Vessey MP, Nunn JF. Occupational hazards of anaesthesia. Br Med J 1980;281:696-8.

17. Waltz LF, Forsythe AB, Moore JG. Critique: occupational disease among operating room personnel. Anesthesiology 1975;42:608-11.

18. Austin SG, Sielken RL, Jr. Issues in assessing the carcinogenic hazards of ethylene oxide. J Occup Med 1988;30:236-45.

19. Hogstedt C, Malmqvist N, Wadman B. Leukemia in workers exposed to ethylene oxide. JAMA 1979;241: 1132-3.

20. Hogstedt C, Rohlen O, Berndtsson BS, Axelson O, Ehrenberg L. A cohort study of mortality and cancer incidence in ethylene oxide production workers. $\mathrm{Br} \mathrm{J}$ Ind Med 1979;36:276-80.

21. Hogstedt LC. Epidemiological studies on ethylene oxide and cancer: an updating. Lyon: International Agency for Research on Cancer, 1988:265-70. (IARC Scientific Publications; no 89.)

22. Gugel EA, Sanders ME. Needle-stick transmission of human colonic adenocarcinoma. N Engl J Med 1986; 315:1487

23. Saxén E, Teppo L. Finnish Cancer Registry 1952-1977: twenty-five years of a nationwide cancer registry. Helsinki: Finnish Cancer Registry, 1978.

24. Ministry of Communications and Public Works. Nordic classification of occupations: Finnish version. Helsinki: Ministry of Communications and Public Works, 1963.

25. International Labour Organisation. International standard classification of occupations. Geneva: International Labour Organisation, 1958.

26. Diem K, ed. Documenta Geigy Wissenschaftliche Tabellen. 6. Auflage. Basel: JR Geigy SA, 1960:107.

27. Breslow NE, Day NE. Statistical methods in cancer research; vol II (The design and analysis of cohort studies). Lyon: International Agency for Research on Cancer, 1987. (IARC scientific publications; no 82.)

28. Nurminen M, Rimpelä A, Pukkala E. Exceptionally low cancer incidence in doctors. Lancet 1988;1:190-1.

29. Asp S, Hernberg S, Collan Y. Mortality among Finnish doctors, 1953-72. Scand J Soc Med 1979;7:55-62.

30. Rimpelä $\mathbf{A H}$, Nurminen MM, Pulkkinen PO, Rimpelä MK, Valkonen T. Mortality of doctors: do doctors benefit from their medical knowledge? Lancet 1987;1: 84-6. 
31. Doll R, Peto R. Mortality among doctors in different occupations. Br Med J 1977;1:1433-6.

32. Lindhardt $M$, Frandsen E, Hamtoft $H$, Mosbech J. Causes of death among the medical profession in Denmark. Dan Med Bull 1963;10:59-64.

33. Byckling $T$, Rimpelä $M$. Lääkärien tupakointitavat muuttuneet [The smoking habits of physicians have changed]. Suom Lääkäril 1985;40:2205-10.

34. Kokko S, Vuori H, Rimpelä M. Lääkärien tupakointitavat Suomessa 1973 [The smoking habits of Finnish physicians in 1973]. Suom Lääkäril 1974;29:1451-4.

35. Pukkala E, Teppo L, Hakulinen T, Rimpelä M. Occupation and smoking as risk determinants of lung cancer. Int J Epidemiol 1983;12:290-6.

36. Doll $\mathrm{R}$, Peto $\mathrm{R}$. Mortality in relation to smoking: 20 years' observations on male British doctors. Br Med $\mathbf{J}$ 1976;2:1525-36.

37. Ahlbom A, Norell S, Rodvall Y. Dentists, dental nurses, and brain tumours. Br Med J 1986;292:662.

38. Harrington JM, Shannon HS. Mortality study of pathologists and medical laboratory technicians. Br Med J 1975;4:329-32.

39. Harrington JM, Oakes D. Mortality study of British pathologists 1974-80. Br J Ind Med 1984;41:188-91.
40. Stroup NE, Blair A, Erikson GE. Brain cancer and other causes of death in anatomists. J Natl Cancer Inst 1986; 77:1217-24.

41. McLaughlin JK, Malker HS, Blot WJ, et al. Occupational risks for intracranial gliomas in Sweden. J Natl Cancer Inst 1987;78:253-7.

42. Morton W, Marjanovic D. Leukemia incidence by occupation in the Portland-Vancouver metropolitan area. Am J Ind Med 1984;6:185-205.

43. Finnish Cancer Registry. Cancer incidence in Finland: annual reports from 1971 to 1980 . Helsinki: Finnish Cancer Registry, 1973-1983.

44. Rimpelä AH, Pukkala EI. Cancers of affluence: positive social class gradient ar 1 rising incidence trend in some cancer forms. Soc Sc. Med 1987;24:601-6.

45. Hemminki K, Kyyrönen P, Lindbohm M-L. Spontaneous abortions and malformations in the offspring of nurses exposed to anaesthetic gases, cytostatic drugs, and other potential hazards in hospitals, based on registered information outcome. J Epidemiol Community Health 1985;39:141-7.

Received for publication: 7 September 1989 